niemożliwe pogodzenie rozumu w demokracji z istnieniem takich sił, lecz doświadczenie uczy nas, że nie istnieją środki, by je zniweczyć ${ }^{35}$.

\title{
Od Sokratesa do Lenina. Georges Sorel i problematyka przemocy w polityce
}

W ypada zgodzić się z uwagą poczynioną przez Gwidona Zelejkę, że „od czasów Heraklita, który w wojnie widział główną siłę wprawiającą świat $\mathrm{w}$ ruch, zjawisko przemocy pojawiało się nieustannie w polu filozoficznej refleksji [...] Dopiero Georges Sorel uczynił z przemocy centralną kategorię filozoficznego namysłu nad społeczeństwem i dziejami. Jego kontrowersyjne tezy ujawniły $\mathrm{z}$ całą ostrością wagę i miejsce problemu" ${ }^{36}$. Uderzające jest jednak, że w Polsce myśl Sorela, szczególnie współcześnie, nie cieszy się zainteresowaniem, zarówno na niwie stricte naukowej, jak i w ramach szerzej zakrojonych dyskusji nad kwestiami społecznopolitycznymi (np. ruch alterglobalityczny). Zdecydowanie odmiennie sytuacja prezentowała się przed drugą wojną światową, a szczególnie za życia Sorela. Przed 1914 rokiem błyskawicznie przekładano jego pisma na język polski $^{37}$, jego myśl zaś zalazła wtedy gorącego orędownika w osobie Stanisława Brzozowskiego $^{38}$; w dwudziestoleciu międzywojennym Kazimierz Wyka

\footnotetext{
Rousseau, stawiając pytanie w sposób abstrakcyjny, wydawał się natychmiast potępiać wszelkie stowarzyszenia i nasze rządy wydawały się przez długi czas opierać na jego autorytecie, by poddać swej władzy wszystkie przejawy stowarzyszania się obywateli.

W. Hanasz, G. Zalejko, Przemoc: między destrukcją a kreacją, [w:] Przemoc. W poszukiwaniu interpretacji, red. W. Hanasz, G. Zalejko, Toruń 1991, s. 7-8.

G. Sorel, Złudzenia postępu, przeł. E. Reiter, Kraków 1912; tenże, O sztuce, religii, filozofii, przeł. M. Rudnicki, Lwów 1913.

„[...] jest Sorel jedną z najwszechstronniejszych i najgłębiej pracujących głów nowoczesnych [...] Za każdym razem, gdy powracam do wielokrotnie już przestudyowanych książek Sorela, czuję się szczęśliwszym, coraz pełniej obejmuję i dostrzegam bezmiar pracy, dokonanej przez tego wielkiego myśliciela i głębokiego człowieka". S. Brzozowski, Legenda Młodej Polski. Studya o strukturze duszy kulturalnej, Lwów 1910. Zob. też: tenże, Pamiętnik, Warszawa 2000 .
} 
twórczości Sorela poświęcił książkę ${ }^{39}$. W późniejszych dekadach, po 1945 roku, próżno szukać większego zainteresowania myślą autora Refleksji o przemocy, nie drukowano ani nie komentowano jego pism, nie powstała także żadna monografia poświęcona jego osobie, czy też myśli ${ }^{40}$. Jest to sytuacja o tyle zaskakująca, że autor ten nie jest bynajmniej twórcą zapomnianym - w zachodnim świecie akademickim regularnie powstają rozprawy poświęcone Sorelowi $^{41}$, ukazują się wznowienia jego dzieł, zaś od połowy lat osiemdziesiątych wydawany jest we Francji rocznik dotyczący wyłącznie jego myśli (od 1987 pod nazwą „Mil neuf cent: Revue d'histoire intellectuelle”). Nim przejdziemy do wprowadzenia do fragmentu pochodzącej z 1908 roku rozprawy Refleksje o przemocy, warto naszkicować pokrótce biografię tego myśliciela.

George Eugene Sorel $^{42}$ (1847-1922) urodził się w Cherbourgu w niezbyt zamożnej katolickiej rodzinie mieszczańskiej ${ }^{43}$. Studia odbył w prestiżowej paryskiej École Politechnique (1865-1870), po czym przez niespełna ćwierć wieku pracował jako inżynier w Departamencie Dróg i Mostów, prowadząc życie - jak charakteryzuje to Isaiah Berlin - „typowe dla drobnego urzędnika francuskiego, spokojne, prowincjonalne i anonimowe" ${ }^{44}$. W roku 1892, niedługo po tym, jak zostaje uhonorowany prestiżowym odznaczeniem Legia Honorowa, odchodzi na emeryturę i poświęca się, zajmującej go już stopniowo od połowy lat osiemdziesiątych ${ }^{45}$, pracy pisarskiej. Dzięki spadkowi po matce osiedla się na stałe na paryskim przedmieściu Boulogne-ur Seine, gdzie mieszka aż do śmierci w 1922 roku.

. Wyka, Jerzy Sorel, Warszawa 1935.

Wyjątek stanowi tu publikacja, inspirowana zapewne Solidarnościowym karnawałem z lat 1980-1981, fragmentu Rozważań o przemocy: G. Sorel, Strajk proletariacki, „Colloquia Communia" 1983 , nr 1, s. 59-81.

Zob. przegląd publikacji dotyczących Sorela: G. Sorel, Reflections on Violence, red. J. Jennings, Cambridge 2004, s. XII-XIV.

42. Wiadomości biograficzne przede wszystkim na podstawie: H. S. Jones, Georges Sorel, [w:] Encyclopedia of nineteenth-century thought, red. G. Clayes, London-New York 2005, s. 615-618; L. Kołakowski, Główne nurty marksizmu, t. II, Rozwój, Poznań, s. 187-189; I. Berlin, Georges Sorel, [w:] tenże, Pod prad. Eseje z historii idei, red. H. Hardy, przeł. T. Bieroń, Poznań, s. 414417. Niezwykle pomocne okazało się także wprowadzenie redakcyjne do nowego wydania Rozważań... w języku angielskim: G. Sorel, Reflections on Violence, red. J. Jennings, Cambridge 2004.

43 Jego kuzynem był Albert-Emile Sorel - jeden z największych historyków doby Trzeciej Republiki, członek Akademii Francuskiej w latach 1894-1906.

W 1889 opublikował, napisane w duchu konserwatywnym, swoje dwie pierwsze książki: Contribution a l'étude profane de la Bible oraz Le Procés de Socrate. 
Biorąc pod uwagę ten czysto materialny aspekt życia Sorela, ciężko zaliczyć ów żywot do szczególnie burzliwych: brak tu motywu uwięzienia, wygnania czy podobnych temu dramatycznych okoliczności, które zwykliśmy wyczytywać z życiorysów wielu myślicieli politycznych tamtej doby, szczególnie zaś tych o proweniencji lewicowej. Tym niemniej życiu Sorela należy się, jak sądzę, uwaga znacznie bardziej wnikliwa, szczególnie jeśli rozważymy jego wymiar intelektualno-polityczny. $\mathrm{W}$ tej dziedzinie był on bowiem prawdziwym ,awanturnikiem”.

Chcąc jednym słowem określić ów aspekt życia Sorela, należałoby powiedzieć: „niestały”. Stąd też nie dziwi, że pierwszy zwrot ideowy w jego życiorysie rozpoznajemy $\mathrm{u}$ samego progu jego politycznych angaży, tj. w ostatniej dekadzie dziewiętnastego wieku. Wówczas to, zafascynowany marksizmem, odrzuca Sorel wyznawane dotąd legitymizm i tradycjonalizm. To oczarowanie mija jednak dosyć szybko i już w drugiej połowie lat dziewięćdziesiątych sprzymierza się on z ruchem syndykalistycznym Fernanda Pelloutiera. Zaczyna współpracować z lewicowymi pismami: efemerycznym „L’Ère Nouvelle”, „La Jeunesse Socialiste” czy - założonym wspólnie z Paulem Lafargiem - „Devenir Social”, ogłaszając tam między innymi studia o Giambattiście Vicu i Emilu Durkheimie. W krytycznym dla polityki francuskiej roku 1898 staje po stronie obrońców Dreyfusa. Publikuje też wówczas rozprawę L'Avenir socialiste des syndicats (1898), co pozwala go traktować jako teoretyka tego ruchu politycznego. W tym okresie rozpoczynają się też jego kontakty z włoskim marksistą Antoniem Labriolą. Wedle Benedetta Crocego - z którym w owym czasie nawiązuje trwającą zresztą wiele lat korespondencyjną przyjaźn - był to decydujący krok w rozwoju włoskiego marksizmu szczególnie w jego teoretycznym wymiarze ${ }^{46}$.

Na początku pierwszej dekady dwudziestego wieku, pod wpływem będących wówczas filozoficzną nowością pism Henriego Bergsona, rozpoczyna się nowy okres twórczości Sorela, przynoszący idee i pomysły, które w późniejszych dekadach będą w pierwszym rzędzie stanowiły o wyjątkowości jego myśli: teorię mitu społecznego, permanentnej walki klasowej, przemocy oraz strajku generalnego. Zawarł je przede wszystkim w swym najsłynniejszym dziele: Refleksje o przemocy (1908) ${ }^{47}$, lecz także i w innych publikowanych $\mathrm{w}$ tym czasie: La Ruine du monde antiques. Conception mate'rialiste de

46 Z. Sternhell, M. Sznajder, M. Asheri, The Birth of Fascist Ideology. From Cultural Rebellion to Political Revoution, przeł. D. Maisel, Princeton 1994, s. 39-40.

47 W 1910 roku związany z monarchistami pisarz Paul Borget publikuje sztukę La Barricade, która okazała się wielkim przebojem paryskich scen. Sztuka zainspirowana była jednym z rozdziałów Rozważań, co przyniosło rozgłos także samemu Sorelowi. Zob. J. J. Roth, Revolution and Morale in Modern French Thought: Sorel and the Sorelians, „French Historical Studies" 1963, nr 2, s. 210. 
l'histoire (1902), Introduction àl'économie moderne (1903), Zludzenia postępu (1906), Le Syste'me historique de Renan (1906), La décomposition du marxisme (1908). Trzeba jednak mieć na uwadze, że z reguły nie były to zwarte traktaty teoretycznopolityczne, ale zbiory tekstów publikowane uprzednio w prasie. Przez niemal całą pierwszą dekadę dwudziestego wieku Sorel niezmiennie wspiera ruch syndykalistyczny, który w 1903 roku nabrał zdecydowanie instytucjonalnego wymiaru jako Confédération Générale du Travail (CGT). Regularnie publikuje przede wszystkim w wydawanym przez Huberta Lagerdelle'a "Mouvement Socialiste”, gdzie w 1906 roku ukazała się zresztą pierwsza wersja Refleksji o przemocy. Zawiera znajomość z poetą i eseistą Charlesem Peguy'em, będąc stałym bywalcem prowadzonej przez niego księgarni.

Choć pod koniec pierwszej dekady w środowisku syndykalistów zdobywa Sorel pozycję wpływowego autorytetu, w połowie 1909 roku publikacją La Révolution dreyfusienne zrywa trwającą już dekadę współpracę z Le Mouvment i ruchem syndykalistycznym, zbliżając się nieoczekiwanie do Action Française - rojalistyczno-nacjonalistycznego ruchu politycznego, kierowanego przez Charlesa Maurassa i Maurice'a Barrès'go. Publikuje w owym czasie w założonym przez Jeana Valois „L'Independance”. Zdaniem Z. Sternhella około roku 1912 myśl Sorela można porównać do późniejszych o dekadę poglądów autorów konserwatywnej rewolucji (Armin Möller van den Bruck, Oswald Spengler, Ernst Jünger), rozwijanej po wojnie w Republice Weimarskiej $^{48}$. Związek z środowiskiem Maurassa okazał się jednak krótkotrwały, opierał się przede wszystkim na fascynacji aktywistycznym potencjałem tego środowiska.

W 1912 rozpoczyna się kolejna polityczna i ideowa wolta Sorela, a mianowicie fascynacja Benitem Mussolinim, wówczas zaledwie redaktorem socjalistycznego pisma „Avanti”, którego do końca życia był gorącym entuzjastą, określając go już po pierwszej wojnie światowej mianem „politycznego geniusza". W latach wojny 1914-1918 Sorel zawiesza publiczną aktywność. W ostatnich, powojennych latach swego życia, już jako siedemdziesięciolatek, fascynację przywódcą włoskich faszystów łączy z podziwem (nieodwzajemnionym jednak) dla Włodzimierza Lenina ${ }^{49}$ - tryumfującego przywódcy bolszewickiej rewolucji w Rosji.

U kresu życia Sorel opublikował jeszcze zbiór pochodzących z różnych lat tekstów Matériaux d'une théorie du prolétariat (1919) oraz De l'Utilité du

${ }^{48}$ Z. Sternhell, M. Sznajder, M. Asheri, The Birth..., s. 80. Por. M. Curtis, Three against the Republic. Sorel, Barrès, Maurass, Princeton 1959.

49 Zob. G. Sorel, In Defence of Lenin, [w:] tenże, Reflections on Violence, s. 283-293. Jest to tekst napisany przez Sorela na okoliczność czwartego wydania Refleksji... 
pragmatisme (1921) - rozprawę poświeconą Wiliamowi Jamesowi. Po jego śmierci w 1922 roku główny organ francuskich komunistów - L'Humanité, z którym współpracował pod koniec życia, napisał, że Refleksje o przemocy mają dla ideologii socjalistyczne znaczenie równe Kapitałowi Marksa i Engelsa. $\mathrm{Z}$ drugiej strony $\mathrm{w}$ latach dwudziestych, wraz z dojściem Mussoliniego do władzy (który w przeciwieństwie do Lenina - jak na ironię dla pozostającego przecież w orbicie socjalizmu Sorela - cenił myśl autora Refleksji, traktując go jako protofaszystę i swojego mistrza ${ }^{50}$ ) rozpoczyna się okres znacznej popularności Sorela we Włoszech.

Zakreślona tu powikłana i nieraz wielce zaskakująca droga Sorela sprzyja bez wątpienia zróżnicowaniu interpretacji jego myśli. Nie powinno więc dziwić, że wśród różnych publikacji w literaturze przedmiotu odnajdujemy ujęcia zaliczające go do tradycji socjalistycznej, jako przedstawiciela „marksizmu jansenistycznego" (Leszek Kołakowski) ${ }^{51}$, syndykalizmu (Jeremy Jennings) ${ }^{52}$ czy marksizmu bergsonistycznego (James Jay Hamilton) ${ }^{53}$, klasyfikujące jego myśl do - obok Gaetana Moskiego, Vilfreda Parety oraz Roberta Michaelsa - dwudziestowiecznego machiavellizmu (James Burnham) ${ }^{54}$ czy wreszcie do tradycji protofaszystowskiej (Zeev Sternhell) ${ }^{55}$. Sytuację w tej materii zdaje się dobrze podsumowuje I. Berlin, pisząc w eseju z 1971 roku, że „postać Sorela pozostaje swoistą anomalią. Inni prorocy i ideolodzy dziewiętnastowieczni zostali bezpiecznie zaszufladkowani i zaklasyfikowani. [...] Sorel pozostaje niezaklasyfikowany, tak jak był za życia. Zawłaszcza go lub dezawuuje zarówno prawica, jak i lewica", ${ }^{, 56}$.

Uznając zatem swoistą złożoność kwestii intelektualnego rodowodu Sorela, nie godząc się jednak na pełną kapitulację w przedstawieniu jego intelektualnego profilu, warto wskazać na zasadnicze rysy jego pisarstwa i tym samym tło dla interpretacji jego politycznych wyborów i sympatii. Jeżeli chce się wyjść z interpretacyjnego impasu, pożyteczne będzie porzucenie pola identyfikacji stricte ideologicznych i spróbowanie określenia generalne-

50 E. Schreiber, L'Illustration, cyt. za: J. H. Meisel, A Premature Fascist? Sorel and Mussolini, „The Western Political Quarterly" 1950, nr 1, s. 14.

51 L. Kołakowski, Główne nurty..., s. 180-211. Lenin podobno zupełnie nie poważał Sorela, traktując go jako ,intelektualnego bałaganiarza” (I. Berlin, Georges Sorel..., s. 414).

J. Jennings, Syndicalism in France: A Study of Ideas, London 1990.

J. J. Hamilton, Georges Sorel and the Inconsistencies of a Bergsonian Marxism, "Political Theory", nr 3, August 1973, s. 329-340. korygującą do pewnego stopnia ujęcie Burnhama, akcentującą odmienność myśli Machiavellego i Sorela w zasadniczych punktach, zawiera tekst: N. Wood, Some Reflections on Sorel and Machiavelli, „Political Science Quarterly”, nr 1, March 1968, s. 76-91.

Z. Sternhell, M. Sznajder, M. Asheri, The Birth....

I. Berlin, Georges Sorel..., s. 414. 
go rysu refleksji Sorela na płaszczyźnie afiliacji filozoficznych i kontekstu politycznego.

Przede wszystkim należy postawić sobie pytanie, z jakim typem refleksji mamy do czynienia w przypadku Sorela. Zdaniem Z. Sternhella autor Refleksji o przemocy nie był ani metafizykiem, ani socjologiem, ani historykiem, ani twórcą literatury, lecz „philosphie” w osiemnastowiecznym sensie tego słowa ${ }^{57}$. Nie chciał być - i faktycznie nie był - twórcą żadnego spójnego systemu. Jego myśl motywowana była logiką stricte polityczną, nieuchronnie więc pozostaje dynamiczna i otwarta. Z tego też powodu, czytając Sorela, warto również pamiętać o dwóch politycznych okolicznościach, które warunkują jego myśl. Przede wszystkim należy zwrócić uwagę na to, że niemal całe dojrzałe życie Sorela upłynęło za czasów istnienia we Francji Trzeciej Republiki. Ustroju tego autor Refleksji o przemocy zupełnie nie poważał, można wręcz powiedzieć, że był on niejako jedną z głównych pobudek (czysto negatywnych) twórczości tego autora. Sorel nie akceptował ustroju ówczesnej Francji, gdyż ten był w jego przekonaniu - i jest to druga ważna okoliczność, o której należy pamiętać - dzieckiem kultury burżuazyjnej, przeciwko której zwrócone było główne ostrze pism filozofa. Dopiero uwzględniając ten kontekst, należy patrzeć na jego, pozornie sprzeczny, podziw i sympatię zarówno dla ultraprawicowego Maurassa, jak i ultralewicowego Lenina. Jak ujmuje to Jack Roth:

Sorel zawsze poszukiwał ricorso, czego prototyp stanowiło prymitywne chrześcijaństwo. Ricorso jest ruchem powodowanym charyzmatycznym rozgorączkowaniem, wyrastającym z dekadencji. Dąży ono do wysublimowanego celu. Poszukiwania Sorela zawsze prowadziły do politycznych ekstremów, do tych, którzy zdawali się [...] najbardziej chętni drastycznej i całkowitej renowacji. Sorel nie był jednak zwykłym obserwatorem, lecz także wierzącym. Wierzył tak głęboko, że często widział w ruchu coś, czego w rzeczywistości nie było. Jego kariera z konieczności stanowiła serię nadziei i oszustw. Zasadniczy pragmatyzm ułatwiał mu przejście $\mathrm{w}$ ekstrema. $\mathrm{Z}$ pewnością najbardziej pragnął ricorso na lewicy. Pęknięcie byłoby bardziej drastyczne, a przemiana kompletniejsza. Odnajdywał w ekstremach nie tylko zasadnicze podobieństwo, lecz [także] osobiście akceptowalne alter- 
natywy. Ekstrema były dla niego jedynie aspektami jedynego systemu myśli, jedynym nastrojem rewolty ${ }^{58}$.

Choć nie sposób określić jego twórczości mianem filozoficznej, można niewątpliwie zidentyfikować w tym obszarze refleksji główne pola inspiracji oraz wskazać na tendencje, którym Sorel się sprzeciwiał. Myśl jego charakteryzuje wrogość wobec racjonalizmu, wskazuje się na inspiracje „élan vital” Bergsona i odrzucenie Arystotelesowskiej phronesis i sophrosyne ${ }^{59}$. Oddziaływali na niego także inni przedstawiciele filozofii życia, jak Gustav Le Bon i Fryderyk Nietzsche, czy pragmatyzm Williama Jamesa. Charakterystyczne dla myśli Sorela jest również zainteresowanie filozofią Giambattisty Vica. Występował przeciwko Kartezjańskiemu racjonalizmowi, optymizmowi, utylitaryzmowi, intelektualizmowi. Jak pisał Sternhell: „Sokrates, Descartes, Wolter, Rousseau oraz Comte, "wielcy poprzednicy» rewolucji francuskiej, a także jej spadkobiercy na czele z Jaures'em - to wszystko wedle Sorela było intelektualną ścieżką, która nieubłaganie prowadziła do dekadencji" ${ }^{60}$. Osobną dziedziną inspiracji dla Sorela jest też Karl Marks, którego autor Refleksji o przemocy był pierwszym poważnym interpretatorem we Francji.

$\mathrm{Na}$ koniec tego biograficznego wprowadzenia - mała uwaga hermeneutyczna. Tradycyjny konserwatysta, marksista, syndykalista, rojalistyczny nacjonalista, a w końcu wielbiciel Mussoliniego i Lenina - tak w sposób sumaryczny prezentuje się droga intelektualna Georga Sorela. Można ową niezwykłość ideowych fluktuacji tłumaczyć łatwo - choćby osobowością autora, dając odpowiedzi wykorzystujące bogaty repertuar nowoczesnej psychologii, czy też zamykające tę kwestię wskazaniem na intelektualną niedojrzałość autora, bądź nawet pneumopatologiczny stan jego duszy czyniący z niego "duchowego eunucha" skażonego gnostyckim aktywizmem (E. Voegelin). Takie - być może nawet trafne -wytłumaczenia gubią jednak wartościową naukę, jaką można wyciągnąć z biografii intelektualnej Sorela, oraz uniemożliwiają postawienie ciekawych pytań o generalnym wymiarze, dotyczących samej epoki, w jakiej Sorel żył, czasu niezwykle istotnego dla zrozumienia natury nowożytności, a w szczególności minionego stulecia. Epoki, którą teraz, z perspektywy dwudziestego pierwszego wieku, można opisać jako rozciągnięty na dziesięciolecia przedburzowy stan europejskiej cywilizacji, którego Sorel był jak się zdaje interesującym barometrem.

J. J. Roth, Revolution and Morale..., s. 220-221.

N. Wood, Some Reflections on Sorel..., s. 90.

Z. Sternhell, M. Sznajder, M. Asheri, The Birth..., s. 37-38. 
Jako samodzielny myśliciel Sorel nie zawsze bywa traktowany poważnie. Nierzadko jego myśli odmawia się charakteru głębokiej refleksji, klasyfikując go wyłącznie jako publicystę lub co najwyżej autora zręcznych pamfletów. Niewątpliwie jednak odważnie wprowadzony przez Sorela do warsztatu refleksji na polityką temat przemocy okazał się kwestią, która w dwudziestowiecznej humanistyce spotkała nadzwyczaj szeroki oddźwięk, także u największych myślicieli tego czasu. Pozostając w obrębie filozoficznej refleksji nad polityką, dość wymienić najważniejszych autorów poruszających tę problematykę: Waltera Benjamina (Zur Kritik der Gewalt ${ }^{61}$ ), Maurice'a Marleau-Ponty'ego (Humanizm i terror ${ }^{62}$ ), Hannah Arendt (O rewolucji, O przemo$c y^{63}$ ), Jacques'a Derridę (Force de loi ${ }^{64}$ ) czy Michela Foucaulta i René Girarda, dla których miała okazać się jedną z podstawowych dla całej ich twórczości. Jeśli zaś spojrzymy na zagadnienie przemocy szerzej, niechybnie zorientujemy się, że stała się kategorią (i zarazem problemem badawczym) niezwykle ważną w obrębie rozmaitych dziedzin akademickich: pedagogiki, irenologii, badań nad terroryzmem, badań nad wojną, antropologii, filozofii kultury, stosunków międzynarodowych czy socjologii w jej rozmaitych działach ${ }^{65}$. Chcąc jednak uniknąć w tym miejscu jałowego wyliczania, poprzestaniemy na zasygnalizowaniu tego, jak szeroki zakres miały w minionym stuleciu dyskusje nad problemem przemocy. Czytelnika zainteresowanego tematyką pozostaje zaś odesłać do samych tekstów wspomnianych wyżej autorów.

$\mathrm{Na}$ koniec warto jeszcze pokreślić, że problem przemocy przetrwał „okrutne stulecie" i nadal stanowi istotną składową refleksji nad polityką. Są ku temu oczywiście jasne powody, jak chociażby zjawisko odradzającego się terroryzmu, jednak w tym miejscu chciałbym wskazać na mniej oczywiste pola, w których można zaobserwować rozwój tej problematyki. Pomimo sygnalizowanych wcześniej kontrowersji dotyczących interpretacji myśli Sorela nie będzie nadużyciem stwierdzić, że sytuuje się on na orbicie lewicowej tradycji myślenia o polityce. $\mathrm{W}$ obrębie tego nurtu zaś na przełomie dwudziestego i dwudziestego pierwszego stulecia pojawiło się kilku myślicieli,

${ }^{61}$ W języku polskim dysponujemy dwoma odrębnymi tłumaczeniami eseju Benjamina: W sprawie krytyki przemocy, przeł. K. Krzemieniowa, [w:] tegoż, Anioł historii. Eseje, szkice, fragmenty, oprac. H. Orłowski, Poznań 1996, s. 27-54, oraz Przyczynek do krytyki przemocy, przeł. A. Lipszyc, „Kronos” 2009, nr 4, s. 26-41. Benjamin w swym eseju odwołuje się do pracy Sorela, nazywając ja głęboką, moralną i autentycznie rewolucyjną. M. Marleau-Ponty, Humanizm i terror, przeł. J. Migasiński, [w:] Marksizm XX wieku, red. M. J. Siemek, J. Dobierzewski, t. II, Warszawa, 1990, s. 235-259.

${ }^{63}$ H. Arendt, O rewolucji, przeł. M. Godyń, Warszawa 2003; taż, O przemocy, przeł. A. Łagodzka, [w:] tejże, O przemocy. Nieposhuszeństwo obywatelskie, Warszawa 1999.

64 J. Derrida, Force de loi, Galilée 1994.

65 W kontekście socjologii zob. bibliografię w: Przemoc. W poszukiwaniu interpretacji..., s. 343361 . 
którzy temat przemocy podjęli w nowy i nieraz zajmujący sposób. Mam tu na myśli przede wszystkim Slavoja Žižka, poruszającego kwestię przemocy w kontekście rewolucyjnej tradycji myśli lewicowej i jej współczesnego znaczenia i aktualności ${ }^{66}$, Giorgia Agambena, analizującego naturę prawa i kondycję współczesnego porządku państwa zachodniego ${ }^{67}$, czy Chantal Mouffe i Ernesta Laclau, których refleksja dotyka natury praktyk polityki demokratycznej $^{68}$

M I C HAE J C C Z A R E C K I

66 Mam tu na myśli głośne komentarze Žižka do pism Robesppierre'a (M. Robespierre, Virtue and Terror, wstęp S. Žižek, oprac. J. Ducange, London 2006; wprowadzenie Žižka ukazało się w języku polskim jako: S. Žižek, Robbespierre, czyli „Boska przemoc” terroru, przeł. J. Kutyła, „Krytyka Polityczna” 2007, nr 13, s. 244-269) oraz Lenina (W. Lenin, Rewolucja u bram. Pisma Lenina roku 1917, oprac. S. Žižek, przeł. J. Kutyła, Kraków 2007), oraz wydaną niedawno: S. Žižek, On violence. Six Sideways Reflections, New York 2008, czy tenże, W obronie przegranych spraw, przeł. J. Kutyła, Warszawa 2008.

G. Agamben, Homo sacer. Suwerenna władza i nagie życie, przeł. M. Salwa, Warszawa 2008 [1995]; tenże, Stan wyjątkowy. Homo sacer II, 1, przeł. M. Surma-Gawłowska, Kraków 2008 [2003]; tenże, Co zostało z Auschwitz: archiwum i świadek, przeł. S. Królak, Warszawa 2008 [1998].

E. Laclau, Ch. Mouffe, Hegemonia i socjalistyczna strategia: przyczynek do projektu radykalnej polityki demokratycznej, przeł. S. Królak, Wrocław 2007 [1985]; E. Laclau, Emancypacje, red. L. Koczanowicz, A. Orzechowski, Wrocław 2004 [1996]; Ch. Mouffe, Paradoks demokracji, przeł. W. Jach, M. Kamińska, A. Orzechowski, Wrocław 2005. 